\title{
Discovering the Mutational Profile of Early Colorectal Lesions: A Translational Impact
}

\author{
Chiara Alquati ${ }^{1,2,+}$, Anna Prossomariti ${ }^{1,2,+}$, Giulia Piazzi ${ }^{1,2}$, Francesco Buttitta ${ }^{1} \mathbb{D}$, Franco Bazzoli ${ }^{1}$, \\ Luigi Laghi ${ }^{3,4}$ and Luigi Ricciardiello ${ }^{1,2, *(1)}$
}

1 Department of Medical and Surgical Sciences, University of Bologna, 40138 Bologna, Italy; chiara.alquati2@unibo.it (C.A.); anna.prossomariti2@unibo.it (A.P.); giulia.piazzi@unibo.it (G.P.); francesco.buttitta@unibo.it (F.B.); franco.bazzoli@unibo.it (F.B.)

2 Center for Applied Biomedical Research (CRBA), University of Bologna, 40138 Bologna, Italy

3 Department of Medicine and Surgery, University of Parma, 43126 Parma, Italy; luigiandreagiuseppe.laghi@unipr.it

4 Laboratory of Molecular Gastroenterology, IRCCS Humanitas Clinical and Research Center, 20089 Rozzano, Italy

* Correspondence: luigi.ricciardiello@unibo.it; Tel.: +39-051-2143381

+ These authors equally contributed to this work.

check for updates

Citation: Alquati, C.; Prossomariti, A.; Piazzi, G.; Buttitta, F.; Bazzoli, F.; Laghi, L.; Ricciardiello, L.

Discovering the Mutational Profile of Early Colorectal Lesions: A

Translational Impact. Cancers 2021, 13, 2081. https://doi.org/10.3390/

cancers13092081

Academic Editor:

Jean-Francois Beaulieu

Received: 2 April 2021

Accepted: 22 April 2021

Published: 25 April 2021

Publisher's Note: MDPI stays neutral with regard to jurisdictional claims in published maps and institutional affiliations.

Copyright: (c) 2021 by the authors. Licensee MDPI, Basel, Switzerland. This article is an open access article distributed under the terms and conditions of the Creative Commons Attribution (CC BY) license (https:// creativecommons.org/licenses/by/ $4.0 /)$.
Simple Summary: Colorectal cancer (CRC) is one of the most common malignancies worldwide. Next-generation sequencing technologies have identified new candidate genes and deepened the knowledge of the molecular mechanisms underlying the progression of colonic adenomas towards CRC. The main genetic, epigenetic, and molecular alterations driving the onset and progression of CRC in both hereditary and sporadic settings have also been investigated. The evaluation of the CRC risk based on the molecular characterization of early pre-cancerous lesions may contribute to the development of targeted preventive strategies development, help define specific risk profiles, and identify patients who will benefit from targeted endoscopic surveillance.

Abstract: Colorectal cancer (CRC) develops through a multi-step process characterized by the acquisition of multiple somatic mutations in oncogenes and tumor-suppressor genes, epigenetic alterations and genomic instability. These events lead to the progression from precancerous lesions to advanced carcinomas. This process requires several years in a sporadic setting, while occurring at an early age and or faster in patients affected by hereditary CRC-predisposing syndromes. Since advanced CRC is largely untreatable or unresponsive to standard or targeted therapies, the endoscopic treatment of colonic lesions remains the most efficient CRC-preventive strategy. In this review, we discuss recent studies that have assessed the genetic alterations in early colorectal lesions in both hereditary and sporadic settings. Establishing the genetic profile of early colorectal lesions is a critical goal in the development of risk-based preventive strategies.

Keywords: colorectal cancer; familial adenomatous polyposis; lynch syndrome; conventional colorectal adenomas; serrated colorectal adenomas

\section{Introduction}

In approximately $75-80 \%$ of cases, colorectal cancer (CRC) occurs sporadically, without a genetic predisposition. At least $10-20 \%$ of CRC cases have a positive family history, and up to $5-7 \%$ of cases develop as a consequence of hereditary CRC-predisposing syndromes [1]. In 1988, Vogelstein and colleagues defined the principles of the adenoma-carcinoma sequence, also known as the "conventional" CRC pathway and first described the molecular bases of CRC evolution. Most CRC cases arise from conventional colorectal adenomas (CNADs) [2]. CNADs (including tubular, tubulovillous, and villous adenomas) are polypoid lesions of the colonic mucosa which, in some cases, evolve into CRC [3]. Subsequently, 
another unconventional pathway was described in the pathogenesis of CRC, also known as the "serrated" pathway [4]. Approximately 15-30\% of CRCs develop from serrated lesions [5-7]. The World Health Organization has classified colorectal serrated lesions as: (i) hyperplastic polyps (HPs), (ii) sessile serrated lesions (SSLs), previously classified as sessile serrated adenomas, (iii) SSLs with dysplasia, (iv) traditional serrated adenomas (TSAs), and (v) unclassified serrated adenomas [8,9]. Traditionally, SSLs and TSAs are pre-cancerous colorectal lesions, while HPs mainly have a low risk of developing CRC.

Several studies have prospectively analyzed the long-term CRC risk in patients with CNADs or serrated lesions and found an increased CRC risk in patients with advanced high-risk adenomas or large serrated polyps [10-15]. A recent study on CRC incidence and mortality in a large cohort of fecal occult blood test positive subjects showed that patients with colorectal neoplastic lesions, regardless of subtype, have an increased risk of developing CRC. The mortality for CRC was higher in patients with SSLs, tubulovillous adenomas, and villous adenomas [16].

The malignant transformation of normal colonic mucosa towards adenoma and then CRC requires the accumulation of genetic and epigenetic alterations. These events occur over an average time span of up to 15 years in the conventional pathway [1]. The genetic drift, however, accelerates these events in hereditary syndromes, implying an early and restricted time frame for surveillance [17]. CRC development through the serrated pathway would also seem to occur more rapidly than the conventional pathway [18].

Three main genetic pathways for CRC development have been described: (i) the chromosomal instability pathway (CIN, $~ 80 \%$ of CRC cases), frequently observed in the conventional pathway and distal CRC, driven by chromosomal alterations / rearrangements, and mutations in known oncogenes (KRAS, BRAF, PIK3CA) and tumor suppressor genes (APC, SMAD4, TP53); (ii) the CpG island methylator phenotype (CIMP, $15-30 \%$ of CRC cases) due to a diffuse $\mathrm{CpG}$ island methylation mostly observed in proximal CRC and frequent in the serrated pathway associated with $B R A F$ mutations; iii) the microsatellite instability pathway (MSI, $15 \%$ of CRC cases), in which the genomic instability is driven by germline (Lynch syndrome-LS) or sporadic inactivation of the mismatch repair (MMR) genes (MLH1, MSH2, MSH6, and PMS2) [19]. Notably these pathways can overlap in CRC pathogenesis and also co-exist within the same tumor [20].

Hereditary CRC syndromes encompass (i) non-polyposis hereditary syndromes including LS, Lynch-like syndrome, familial CRC type X, (ii) polyposis syndromes including familial adenomatous polyposis (FAP), MUTYH-associated polyposis (MAP), and the serrated polyposis syndrome (SPS); and (iii) hamartomatous syndromes including Peutz-Jeghers syndrome, juvenile polyposis syndrome, and PTEN-hamartomatous tumor syndrome $[17,21]$.

Yurgelun and colleagues recently evaluated the presence of germline mutations in a large cohort of unselected CRC patients. Interestingly, they found that approximately $10 \%$ of the patients had germline causative mutations in CRC-predisposing genes as well as in genes not conventionally associated with $C R C$, thus indicating that the percentage of CRC cases due to hereditary defects may be higher than generally thought [22]. Many studies have defined distinct mutational profiles of advanced CRCs $[20,23,24]$ and four distinct consensus molecular subtypes (CMS1-CMS4) for CRC have been described [25] according to their patterns of mRNA expression.

In addition, the somatic mutational cancer signatures in CRC and colonic polyposis have been recently reviewed [26] and various studies have focused on the genetic and molecular characterization of pre-cancerous colonic lesions.

In this review, we discuss recent findings with regard to defining the somatic alterations of both hereditary and sporadic early colorectal lesions. We focus on FAP, MAP, and LS-derived adenomas as part of the hereditary setting, as well as conventional and serrated lesions in the sporadic setting. 


\section{Hereditary Settings}

\subsection{Familial Adenomatous Polyposis and MUTYH-Associated Polyposis}

FAP is an inherited autosomal dominant syndrome clinically characterized by the onset of hundreds to thousands of adenomatous polyps in the gastrointestinal tract at a young age. Given that FAP patients are at high risk of CRC (almost 100\% at a mean age of 39 years), they require close surveillance and endoscopic treatment for CRC prevention. However, most of them need undergoing prophylactic surgery to counteract the progression of polyps towards cancers [27]. Moreover, extra-intestinal clinical manifestations are common in FAP [27]. FAP arises from heterozygous germline mutations in the tumor suppressor $A P C$ gene, leading to aberrant $\mathrm{Wnt} / \beta$-catenin pathway activation and sustained intestinal hyperproliferation [27]. Somatic mosaicism in the APC gene is also a frequent causative event for FAP [28], as well as in sporadic polyposis patients [29].

Unlike FAP, MAP is a hereditary autosomal recessive syndrome caused by germline mutations in the MUTYH gene. Genetic alterations in the MUTYH gene confer an increased CRC risk (from $43 \%$ to $100 \%$ at 48 years) due to the improper functioning of one of the DNA damage repair mechanisms. The clinical phenotype of MAP patients resembles attenuated FAP, typically presenting from 10 up to 100 colorectal polyps [30,31]. Although the genetic basis for these syndromes is known, many studies conducted in recent years have characterized the somatic alterations that cause the progression of adenomas in these patients (Table 1).

Table 1. Studies evaluating somatic mutations in colorectal adenomas and cancers from patients with hereditary CRC syndromes.

\begin{tabular}{|c|c|c|c|c|c|c|}
\hline Syndrome & Study Population & Samples Analyzed & Study Methods & $\begin{array}{c}\text { Frequent Mutated Genes } \\
\text { and Candidate Driver } \\
\text { Genes }\end{array}$ & Notes & References \\
\hline FAP & 12 FAP patients & $\begin{array}{c}25 \text { adenomas, } \\
10 \text { adjacent } \mathrm{NM}\end{array}$ & WES & $\begin{array}{c}\text { APC, KRAS, FBXW7, } \\
\text { TCF7L2, BRCA2, ALK, } \\
\text { CNOT3, ARID1A, CDC27, } \\
\text { EWSR1, GNAQ, TTN, } \\
\text { PCMTD1 }\end{array}$ & & [32] \\
\hline FAP & 14 FAP patients & $\begin{array}{l}37 \text { adenomas and } \\
\text { matched NM }\end{array}$ & $\begin{array}{l}\text { Targeted Ampliseq } \\
\text { sequencing }\end{array}$ & $A P C, K R A S$ & & [33] \\
\hline FAP and MAP & $\begin{array}{l}5 \text { FAP patients } \\
1 \text { MAP patient }\end{array}$ & $\begin{array}{l}20 \text { LGD adenomas, } \\
4 \text { HGD adenomas, } 7 \\
\text { carcinomas and } 8 \\
\text { adjacent NM }\end{array}$ & $\begin{array}{l}\text { WES, } \\
\text { WGS }\end{array}$ & $\begin{array}{c}\text { APC (69\%), TTN (37\%), } \\
\text { SMAD4 (35\%), GNAS } \\
(33 \%), \text { ASXL1 }(33 \%), \text { KRAS } \\
(23 \%), \text { FAT4 }(22 \%), \text { ZFHX3 } \\
(22 \%), \text { FBXW7 (22\%), } \\
\text { PTPRT }(20 \%), \text { SOX9 }(16 \%)\end{array}$ & $\begin{array}{c}\text { Additional potential } \\
\text { driver events with lower } \\
\text { frequency: ERBB3 }(8 \%), \\
\text { ARID1A }(8 \%), \text { TP53 }(8 \%), \\
\text { ACVR2A (6\%), EPHA5 } \\
(6 \%), \text { TCF7L2 (6\%), } \\
\text { PIK3CA (6\%), RBM10 } \\
\text { (5\%), CTNNB1 (5\%), } \\
\text { ATM (5\%), AMER1 (5\%). }\end{array}$ & [34] \\
\hline \multirow{3}{*}{ FAP and MAP } & $\begin{array}{l}2 \text { FAP patients and } \\
2 \text { MAP patients }\end{array}$ & $\begin{array}{l}6 \text { adenomas } \\
8 \text { adenomas }\end{array}$ & & \multirow{3}{*}{$\begin{array}{c}\text { APC, KRAS, } \\
\text { WTX/FAM123B, SCUBE2, } \\
\text { RELN, FBXW7, MLL3, } \\
\text { OTUD7B, KPRP, ATRNL1, } \\
\text { MAP3K5, NRAS, PLCG2, } \\
\text { PTEN, TP53 }\end{array}$} & \multirow{3}{*}{$\begin{array}{c}\text { Except for APC, WTX } \\
\text { and KRAS, few } \\
\text { adenomas shared the } \\
\text { same set of mutated } \\
\text { driver genes }\end{array}$} & \multirow{3}{*}{ [35] } \\
\hline & $\begin{array}{l}3 \text { FAP patients and } \\
4 \text { MAP patients }\end{array}$ & $\begin{array}{l}22 \text { adenomas } \\
33 \text { adenomas }\end{array}$ & $\begin{array}{l}\text { Targeted exome } \\
\text { sequencing }\end{array}$ & & & \\
\hline & $\begin{array}{l}7 \text { FAP patients and } \\
3 \text { MAP patients }\end{array}$ & $\begin{array}{l}41 \text { adenomas } \\
22 \text { adenomas }\end{array}$ & $\begin{array}{c}\text { WTX/KRAS } \\
\text { capillary } \\
\text { sequencing }\end{array}$ & & & \\
\hline \multirow[t]{2}{*}{ Lynch } & \multirow[t]{2}{*}{44 patients } & $\begin{array}{c}86 \text { adenomas, } \\
36 \text { adenocarcinomas }\end{array}$ & & $\begin{array}{l}A P C(40 \% \text { of LS-associated } \\
\text { adenomas, } 28 \% \text { of }\end{array}$ & \multirow[b]{2}{*}{$\begin{array}{c}\text { KRAS, BRAF and NRAS } \\
\text { mutations uncommon in } \\
\text { both LS- and sporadic } \\
\text { adenomas }\end{array}$} & \multirow[b]{2}{*}{ [36] } \\
\hline & & $\begin{array}{l}84 \text { sporadic } \\
\text { adenomas }\end{array}$ & Target NGS & $\begin{array}{c}\text { LS-adenocarcinomas and } \\
60 \% \text { sporadic adenomas); } \\
\text { CTNNB1 (5\% LS-adenomas } \\
\text { and 10\% sporadic } \\
\text { adenomas); RNF43 ( } 52 \% \\
\text { LS-associated adenomas; } \\
56 \% \text { LS-adenocarcinomas). }\end{array}$ & & \\
\hline
\end{tabular}


Table 1. Cont.

\begin{tabular}{|c|c|c|c|c|c|c|}
\hline Syndrome & Study Population & Samples Analyzed & Study Methods & $\begin{array}{c}\text { Frequent Mutated Genes } \\
\text { and Candidate Driver } \\
\text { Genes }\end{array}$ & Notes & References \\
\hline Lynch & 57 patients & $\begin{array}{l}59 \text { adenomas: } 16 \\
\text { MMR-P; } 43 \text { MMR-D } \\
\text { (41 LGD and } \\
18 \text { HGD) }\end{array}$ & $\begin{array}{l}\text { Amplicon-based } \\
\text { NGS }\end{array}$ & $\begin{array}{c}\text { TP53 }(24 \%), \text { KRAS }(22 \%), \\
\text { SMAD4 }(19 \%), \text { CTNNB1 } \\
(15 \%)\end{array}$ & $\begin{array}{c}\text { Additional potential } \\
\text { driver events with lower } \\
\text { frequency: ALK (2\%), } \\
\text { BRAF }(9 \%), D D R 2(2 \%), \\
\text { EGFR }(10 \%), E R B B 2 \\
(3 \%), E R B B 4(5 \%), \\
\text { FBXW7 }(9 \%), F G F R 1 \\
(2 \%), \text { FGFR2 (3\%), MET } \\
(2 \%), \text { NOTCH1 (5\%), } \\
\text { PTEN }(10 \%), \text { PIK3CA } \\
\text { (5\%), STKI1 (3\%) }\end{array}$ & [37] \\
\hline Lynch & 11 patients & $\begin{array}{l}\text { Paired tumor } \\
\text { (adenoma and } \\
\text { cancer) and } \\
\text { tumor-distant NM }\end{array}$ & $\begin{array}{l}\text { Whole- genome } \\
\text { DNA- sequencing }\end{array}$ & $\begin{array}{c}\text { ACVR2A, TGFBR2, CDC27, } \\
\text { AIM2, PDS5B, TP53, KRAS } \\
\text { (Frequent in the G1 } \\
\text { LS-CRC subgroup) }\end{array}$ & $\begin{array}{l}\text { Paired patient-matched } \\
\text { specimens of tumors } \\
\text { were stratified into two } \\
\text { subgroups based on } \\
\text { their genomic } \\
\text { characteristics (G1 with } \\
\text { higher amount of } \\
\text { mutation and MS } \\
\text { slippage than G2) }\end{array}$ & [38] \\
\hline
\end{tabular}

FAP (Familial Adenomatous Polyposis); MAP (MUTYH-associated Polyposis); NM (Normal Mucosa); LGD (Low-Grade Dysplasia); HGD (High-Grade Dysplasia); WES (Whole-Exome Sequencing); WGS (Whole-Genome Sequencing); NGS (Next-Generation Sequencing); MMR-P (MMR-proficient); MMR-D (MMR-deficient); MS (microsatellite). The frequency of mutations (\%) is shown for those studies that have reported them.

\section{Somatic Mutational Profile in FAP and MAP}

The somatic mutational profile of colorectal pre-cancerous lesions in FAP was recently investigated in a study on 25 colorectal adenomas and adjacent normal mucosa from $12 \mathrm{FAP}$ patients with confirmed germline $A P C$ gene mutations through whole-exome sequencing (WES) [32]. This study confirmed the pivotal effect of Wnt signaling alterations in the early stages of colorectal carcinogenesis in these patients. In fact, a somatic second hit in the APC gene was found in most adenomas (72\%) and a small fraction of sequenced adenomas also had further somatic mutations in Wnt signaling pathway components including TCF7L2. Damaging somatic mutations on KRAS and FBXW7 genes also occurred, as well as potential deleterious mutations in additional genes including CNOT3, EWSR1 and PCMTD1 (Table 1). Allelic imbalance was also frequently observed in the analyzed adenomas and validated in an additional cohort of 37 adenomas from 14 FAP patients. In particular, the loss of $5 q$ and amplifications in chromosomes 7 and 13 appeared to be relevant in the early phases of colonic transformation. The authors also showed an early development of intra-tumor heterogeneity (ITH) since most adenomas harbored sub-clones arising from an $A P C$-mutant founder clone [32].

Multiple somatic inactivating mutations in the APC and KRAS genes have also been found in a study on $37 \mathrm{FAP}$-derived adenomas. The study provided further evidence about the early onset of ITH in colorectal tumorigenesis, demonstrating that APC-mutant adenomas have polyclonal characteristics with different mutations arising from independent lineages. Specifically, the analysis of individual colonic crypts isolated from adenomas of patients with distinct hereditary polyposis syndromes, as well as from sporadic and Lynch-syndrome derived carcinomas, demonstrated that the ITH for both APC and KRAS alterations was detectable in single crypts [33] (Table 1). These results suggest that multiple clones may compete for malignant transformation within the same pre-cancerous lesion.

Combining next-generation sequencing (NGS) with single-cells transcriptomic analysis, new data have been provided on the genetic and transcriptomic alterations occurring in the transition from adenomas to carcinoma in FAP individuals. The authors performed WES, whole-genome-sequencing (WGS) and single-cell-RNA-sequencing on normal mucosa, adenomas and carcinomas from five FAP patients and one patient with MAP. In line with previous studies, the authors showed that somatic inactivation of the APC gene constitutes the most frequent event in adenomas from FAP patients and that the derangements of Wnt signaling represented the most affected pathway. Considering all the samples 
analyzed (including normal mucosa) in this study from FAP patients and the single patient with MAP, the authors found that potential driver alterations in TTN, SMAD4, GNAS, ASXL1, KRAS, FAT4, ZFHX3, FBXW7, PTPRT, and SOX9 genes occur with a frequency of between $37 \%$ and $16 \%$ (Table 1). In addition, by analyzing multiple adenomas from individual patients, it was found that different lesions collected from closely related colonic areas might originate from the same cell following a field cancerization process. By sequencing multiple regions within the same lesion, the authors observed ITH as well intertumoral heterogeneity in pre-cancerous lesions, confirming that both occur in the early phases of colonic carcinogenesis. Finally, morphologically normal colonic mucosa from FAP patients had a transcriptomic profile indicative of an early metabolic switch typical of cancer cells, particularly regarding the carbohydrate metabolism, as well as a hyperproliferative signature [34].

A characterization of the somatic mutational profile performed with WES of colorectal adenomas from FAP and MAP patients showed that adenomas from MAP patients had a higher rate of missense and nonsense mutations compared with FAP adenomas, due to genetic defects in the MUTYH gene. Moreover, APC, KRAS, and WTX (AMER1) genes were frequently mutated in pre-cancerous lesions from these patients. In particular, $A P C$ somatic mutations occurred in 50\% of the tumors in this study [35] (Table 1). Mutations in the WTX gene, encoding for a negative regulator of Wnt/ $\beta$-catenin signaling [39], have also been associated with sporadic CRC [40], and might contribute to CRC initiation [35].

A subsequent study employing WES analyzed the somatic mutational signature of multiple duodenal adenomas, which represent a frequent extra-colonic manifestation in these syndromes, from 16 FAP and 10 MAP patients, respectively [41]. Similarly to colorectal adenomas, duodenal adenomas from MAP patients also had an increased mutational burden compared with FAP adenomas. Most somatic mutations found in MAP adenomas were $\mathrm{G}>\mathrm{T}$ transversions. Unlike colorectal adenomas, no mutations in the WTX gene were identified in duodenal adenomas. On the other hand, APC and KRAS have been found to be recurrently mutated also in duodenal adenomas. Moreover, PTCH2, ERBB2 and PCL1 genes have also been found to be potentially involved in duodenal carcinogenesis in these patients [41].

\subsection{Lynch Syndrome}

LS is the most frequent hereditary CRC-predisposing syndrome with an autosomal dominant pattern [42]. Germline mutations in the mismatch repair (MMR) genes, particularly $M L H 1, M S H 2, M S H 6$, and PMS2, are causative for LS development together with EPCAM gene deletions which result in $M S H 2$ epigenetic silencing [42].

The inactivation of MMR genes thus represents the mechanism underlying LS tumors onset and progression [43]. However, the identification of small low-grade adenomas with intact MMR genes in these patients suggests that additional events and factors may be involved in LS-associated adenoma development [43-46]. Although MSI is the hallmark of LS-CRCs [45,47], data are conflicting on the precise timing of complete MMR inactivation during tumorigenesis in LS patients.

Somatic Mutational Profile in LS Tumors

Using NGS, Sekine and colleagues investigated the genetic profile of colonic lesions from 44 LS patients and 84 sporadic colorectal adenomas. Most adenomas and all the adenocarcinomas from LS patients were MMR-deficient (MMR-D) and characterized by high-grade MSI. On the other hand, all the sporadic adenomas analyzed were MMRproficient (MMR-P) and microsatellite stable (MSS) [36]. The genetic profile of colonic lesions showed that RNF43 gene mutations were frequent in both LS-associated adenomas and adenocarcinomas, while APC gene mutations, despite being detected in $40 \%$ of LSadenomas, were more frequent in sporadic colorectal adenomas (60\% of cases) (Table 1). The authors observed a distinct somatic mutational profile in LS-associated adenomas depending on the MMR status, and supported the concept that MMR-deficiency occurs 
prior to the formation of adenoma in LS patients. In particular, MMR-D adenomas were characterized by RNF43 frameshift somatic mutations in mononucleotide repeats, frequently associated with insertions or deletions of three-repeat sequences in the APC gene. By contrast, MMR-P adenomas had a higher frequency of APC and CTNNB1 somatic mutations, but no RNF43 somatic mutations [36] (Table 1). Otherwise, other studies provided evidence of a late MMR inactivation in LS since the loss of MMR proteins has mainly been found in adenomas with high-grade dysplasia [37,48].

The mutually-exclusive relationship between RNF43 and CTNNB1 mutations in LS tumors was confirmed in another study which defined two subgroups of LS-CRCs (G1 and G2), characterized by different amounts and patterns of somatic mutations and microsatellite (MS) slippage [38]. The G1 LS-CRCs subgroup, characterized by the higher amount of mutations and MS slippage, was associated with MLH1 impairment and somatic mutations in KRAS, TP53, POLE, MSH3, ACVR2A, TGFBR2, CDC27, AIM2, and PDS5B genes. However, the G2 subgroup had a lower degree of MS instability and mutation rate [38] (Table 1). In addition, a transcriptomic analysis of LS adenomas showed increased expression of colonic stem cell markers CD44, BIRC5, CCND1, MYC and ASCL2, which contribute to sustaining stem cells proliferation in colonic crypts. In particular, $M Y C$ induction in the G1 LS-CRCs subgroup, seems to be mainly associated with somatic mutations in ACVRA, TCF7LA, and TGFBR2 genes [38].

When DNA methylation changes and somatic mutations in formalin-fixed and paraffinembedded tissues from 57 LS patients were investigated, targeted-NGS showed that somatic mutations in LS-adenomas frequently affect CTNNB1, SMAD4, KRAS, and TP53 genes, with a frequency from $15 \%$ up to $24 \%$ respectively. In addition, a higher mutation rate was in MMR-D adenomas than in MMR-P lesions [37] (Table 1).

Recent findings have shown distinct associations between MMR mutations and cancer risks [49,50] (Supplementary Table S1). A prospective study demonstrated that carriers of MSH2 mutations show the highest risk of developing adenomas and advanced adenomas, probably as a consequence of the association between germline $\mathrm{MSH} 2$ alterations and somatic APC gene mutations which may contribute to accelerate the colonic malignant transformation [49]. Although carriers of $\mathrm{MSH} 6$ germline mutations, who exhibit a lower amount of MMR-D adenomas, had a great incidence of adenomas, patients with $\mathrm{MSH} 2$ and MLH1 germline mutations showed the highest risk of early CRC onset [36,49,51] (Supplementary Table S1). In addition, patients with PMS2 germline mutations had a lower CRC risk, a high frequency of MMR-P adenomas and were negative for CTNNB1 somatic mutations. On the other hand, CTNNB1 somatic mutations were frequent in MLH1-mutant CRCs [52] (Supplementary Table S1).

The correlation between CTNNB1 somatic mutations and MLH1 germline mutations was confirmed in another study, which suggested that MLH1-mutant cancers may develop from MMR-deficient crypt foci (MMR-DCF) [49]. MMR-DCF have been described as a new LS-associated lesions, displaying a loss of MMR protein expression, MSI and a distinct non-adenomatous phenotype associated with a rapid invasive growth. In this setting, CTNNB1 somatic mutations associated with MMR deficiency may possibly act as driver events for LS cancer progression [53].

Based on the concept that MMR-deficiency may occur both as early or late events, three different LS CRC pathways were recently proposed [54]. In fact, according to this hypothesis, LS-associated CRCs may develop following the expansion of adenomas in a MMR-P setting, in which the loss of functional MMR genes is a later event $(23 \%$ of LS adenomas). Most LS CRCs are associated with early MMR proteins loss and would develop from MMR-D adenomas or MMR-DCF [54]. Importantly, LS-CRCs derived from MMR-DCF represent only 3.3\% of cases [54]. Ahadova and colleagues found that somatic mutations in APC and KRAS genes were mainly associated with MMR-D adenomas in LS patients. The occurrence of these mutations was predicted as a secondary event following MMR-deficiency in MMR-D adenomas. CTNNB1 and TP53 somatic mutations have been 
described as an early event in MMR-DCF [54]. In fact, TP53 somatic mutations have also been identified in LS-associated adenomas.

Interestingly, most TP53 somatic mutations have been found in MMR-P adenomas or low-grade dysplastic adenomas. Somatic KRAS mutations (G12V and A146T) have also been observed above all in MMR-P adenomas, rather than MMR-D [37,38].

\section{Sporadic Colorectal Adenomas}

\subsection{Conventional Colorectal Adenomas}

Most CRCs arising from CNADs develop following the canonical adenoma-carcinoma sequence, characterized by the accumulation, through a multi-step process, of mutational events in both driver and passenger genes [2].

In $80-90 \%$ of CRC cases, the initiating mutational event arises in the APC tumor suppressor gene. The subsequent mutational events mainly affect the KRAS/NRAS and TP53 genes. TP53 mutations are also traditionally associated with TGF- $\beta, S M A D 4$ and PI3KCA mutations during the later phases of adenoma-carcinoma transition [55]. Despite being more frequent in the advanced stages of colorectal tumorigenesis, there is also evidence of TP53 mutations in normal colon epithelial stem cells [56], as well as in early and premalignant colorectal adenomas [57-59].

Although genetic alterations in CRC are well characterized, the genetic and molecular events, which take place during the early stages of tumorigenesis, remain largely unknown. The accumulation of somatic mutations during the adenoma-carcinoma transition is crucial for CRC development $[56,60,61]$. In this context, the diffusion of NGS techniques has increasingly led to enhancements in understanding the complexity of the tumor mutational landscape [62]. Table 2 summarizes the frequent mutated and new driver genes found in both conventional and serrated adenomas in recent studies. 
Table 2. Studies evaluating somatic mutations in sporadic conventional and serrated colorectal lesions.

\begin{tabular}{|c|c|c|c|c|c|}
\hline Study Population & Samples Analyzed & Study Methods & Frequent Mutated Genes and Candidate Driver Genes & Notes & Reference \\
\hline 36 patients & $\begin{array}{l}48 \text { colorectal polyps: } 33 \text { tubular adenomas, }, 5 \\
\text { tubulovillous adenomas, } 4 \mathrm{SSLs}, 6 \mathrm{HPs}\end{array}$ & Target NGS & $\begin{array}{c}\operatorname{APC}(67 \%), \operatorname{KRAS}(15 \%), \operatorname{NRAS}(2 \%), \operatorname{TPS3}(8 \%), \operatorname{FBXW7}(10 \%), \operatorname{BRAFV} 600 \mathrm{E}(17 \%, \\
\text { mainly in SSLs and HPs) }\end{array}$ & & [57] \\
\hline 58 patients with colorectal adenomas (retrospective study) & $\begin{array}{l}85 \text { samples from } 58 \text { adenomas } \geq 2 \mathrm{~cm}: 19 \mathrm{LGD} \\
\text { adenomas (10 tubulararand } 9 \text { tubulovillous adenomas); } \\
21 \text { premalignant adenomas; } 28 \mathrm{HGD} \text { adenomas; and } 17 \\
\text { invasive adenocarcinomas }\end{array}$ & Target NGS & 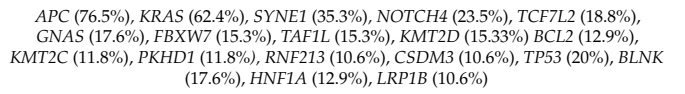 & $\begin{array}{l}\text { The percentages refer to all the analyzed } \\
\text { adenomatous samples. Dota on cancer samples are } \\
\text { described in Supplementary Table S2 }\end{array}$ & [58] \\
\hline $\mathrm{NA}$ & $\begin{array}{l}149 \text { adenomas from two independent projects: } 100 \\
\text { CNADs (first study); } 35 \text { CNADS and } 14 \text { SSLs (second } \\
\text { study) }\end{array}$ & WES and Target sequencing & 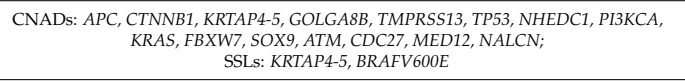 & & [60] \\
\hline 2 CRC patients & $\begin{array}{l}24 \mathrm{NM} \text { single cells; } 48 \text { adenoma single cells (tubular } \\
\text { adenomatous polyps and inflammantory fibroid polyp } \\
\text { normal appearance) }\end{array}$ & single-cell WES and bulk WES & OR1B1, DCDC5, CSMD1, FBXO15, TCP11, TFAP2D & $\begin{array}{l}\text { Small sample size. } \\
\text { Data on CRC single cells are described in } \\
\text { Supplementary Table S2 }\end{array}$ & [63] \\
\hline $\begin{array}{l}2 \text { large prospective cohorrt studies: Nurses' Health Study } \\
\text { (N = 121,700 women followed since 1976) and Health } \\
\text { Professionals Follow-up Study }(\mathrm{N}=51,500 \text { men followed } \\
\text { since 1986) }\end{array}$ & $\begin{array}{c}225 \text { colorectal } \\
\text { cancers LGD (=50\% gland formation) vs. HGD }(<50 \% \\
\text { gland formation) }\end{array}$ & $\begin{array}{l}\text { Pyrosequencing } \\
\text { and Sanger sequencing }\end{array}$ & $\begin{array}{l}\text { NRAS activating mutations }(5 / 225 \mathrm{CNADs} s .34 \mathrm{C}>\mathrm{A}, \mathrm{c} .35 \mathrm{G} \rightarrow \mathrm{A} \text { and } \mathrm{c} .35 \mathrm{G}>\mathrm{T} \text { in codon } \\
12 \text { and c.181C>A in codon } 61)\end{array}$ & Only NRAS mutations were analyzed in this study & [64] \\
\hline 12 Korean patients & $\begin{array}{l}12 \text { high-grade colon adenoma samples }(11 \\
\text { non-hypermutated and } 1 \text { hypermutated } \\
\text { (POLE-mutated) tubulovillous adenomas) and matched } \\
\text { NM }\end{array}$ & WES & 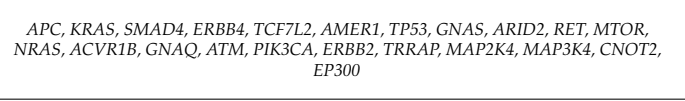 & & [65] \\
\hline 31 patients & $\begin{array}{l}90 \text { tissues: } 16 \text { CAP cases matched with } 15 \text { CFP cases-all } \\
\text { polyps are adenomatous polyps with villous features } \\
\text {-tubulovillous or } \\
\text { villous-and LGD) }\end{array}$ & WES & $\begin{array}{l}\text { TPS3, FBXW7, PIK3CA, KIAA1804, SMAD2 and SMAD4 (mutations exclusively in } \\
\text { CAP samples); } A P C \text { (significantly mutated in both polyp groups, } 70 \% \text { CFPs and } 80 \% \\
\text { CAPs); } M U C 19 \text { (CFPs) }\end{array}$ & & [66] \\
\hline $\begin{array}{l}20 \text { patients with multiple SSLs } \\
\text { (16 fulfill WHO clinical criteria for SPS) }\end{array}$ & $\begin{array}{c}1 \text { SSL from each } \\
\text { individual }(19 / 20)\end{array}$ & $\begin{array}{c}\text { BRAF/ } \\
\text { KRAS } \\
\text { SNaPshot genotyping }\end{array}$ & BRAFV600E (18/19 SSLs) & & [67] \\
\hline $\begin{array}{l}5 \text { patients(carriers of } R N F 43 \text { c.953-1, G>A germline } \\
\text { mutation) from } 1 \text { SPS family }\end{array}$ & $\begin{array}{l}16 \text { serrated lesions (SSLs/TSAs/ HPs), } 5 \text { tubulovillous) } \\
\text { villous adenomas and 1 cancer (from } 5 \text { SPS patients); } \\
90 \text { sporadic lesions (14 HPs, 47 SSLs / TSAs, } 29 \text { CNADs); }\end{array}$ & WES, Target Gene Sanger Sequencing & 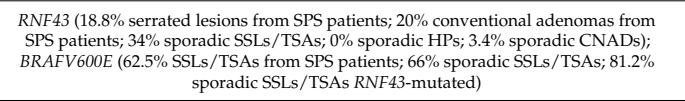 & $\begin{array}{l}\text { SSLs and TSAs analyzed as a single group. } \\
\text { Data on cancer samples are edecribed in } \\
\text { Supplementary Table S2 }\end{array}$ & [68] \\
\hline $\mathrm{NA}$ & $\begin{array}{l}20 \text { SSLs; } 36 \text { TSAs; } 37 \text { TSAs with cytologic dysplasia; } 30 \\
\text { tubulovillous/ villous adenomas }\end{array}$ & Sanger sequencing & 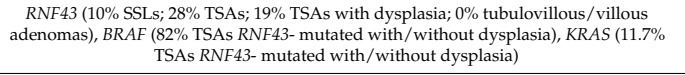 & $\begin{array}{l}\text { Data on cancer samples are reported in } \\
\text { Supplementary Table S2 }\end{array}$ & [69] \\
\hline $\mathrm{NA}$ & $\begin{array}{l}130 \text { serrated lesions ( } 26 \mathrm{HPs}, 34 \text { SSLs, } 70 \text { TSAs) and } 58 \\
\text { CNADs (27 tubular adenomas, } 31 \text { tubulovillous } \\
\text { adenomas) }\end{array}$ & Target NGS, Sanger sequencing & $\begin{array}{l}\text { RNF43 (6\% SSLs; } 24 \% \text { TSAs; } 0 \% \text { CNADS); BRAF (73\% HPs; } 74 \% \text { SSLs; } 60 \% \text { TSAs; } 0 \% \\
\text { CNADs); APC (0\% HPs and SSLs; } 13 \% \text { TSAs; } 59 \% \text { CNADs) }\end{array}$ & & [70] \\
\hline NA & 46 dysplastic SSLs; 45 SSLs without dysplasia & Target NGS, Sanger sequencing & $\begin{array}{l}\text { RNF43 (50\% dysplastic SSLs); }) \text { APC (9\% dysplastic SSLs), ZNRF3 (7\% dysplastic SSLs); } \\
\text { BRAF (87\% dysplastic SSLs; 84\% SSLs without dysplasia) }\end{array}$ & & [71] \\
\hline 196 patients & $\begin{array}{l}200 \text { TSAs (162 ordinary, } 38 \text { advanced); } 50 \text { tubulovillous } \\
\text { adenomas }\end{array}$ & Allele Specific PCR & BRAFV $600 E(6 \% \%$ TSAs) & & [72] \\
\hline 8 patients & $\begin{array}{l}\text { 8SSLS: } 4 \text { SSLs with HGD, } 4 \text { SSLs with submucosal } \\
\text { carcinoma }\end{array}$ & Target NGS & $\begin{array}{c}\text { BRAFV V600E (88\% SSLs); FBXW7 (38\% SSLs); TP53 (25\% SSLs); KIT, PTEN, SMAD4, } \\
\text { SMARCB (13\% SSLs each) }\end{array}$ & & [73] \\
\hline $\mathrm{NA}$ & $\begin{array}{l}189 \text { samples: } 20 \text { SSLs; } 20 \text { dysplastic SLLs; } 14 \text { TSAs; } 6 \\
\text { dysplastic TSAs; } 19 \text { tubular and tubulovillous } \\
\text { adenomas }\end{array}$ & Targeted amplicon sequencing & $\begin{array}{l}\text { APC (5\% SSLs; } 20 \% \text { dysplastic SSLs; 36\% TSAs; 33\% dysplastic TSAs; } 89 \% \text { tubular } \\
\text { and tubulovillous adenomas) }\end{array}$ & $\begin{array}{l}\text { Only APC mutations were analyzed in this study. } \\
\text { Data on cancer samples are reported in } \\
\text { Supplementary Table S2 }\end{array}$ & [74] \\
\hline NA & $\begin{array}{l}15 \text { TSAs associated with precursors polyps: } 9 \text { associated } \\
\text { with HPs and } 6 \text { associated with SSLs } \\
\end{array}$ & Laser microdissection based sequencing & RNF43, APC, CTNNB1; BRAFV600E & & [75] \\
\hline
\end{tabular}

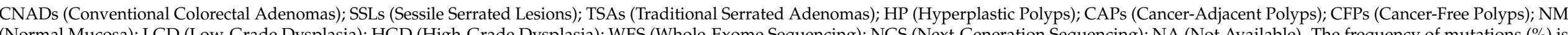

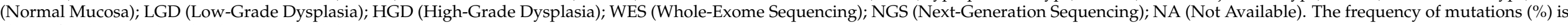

shown for those studies that have reported them 
Using target-NGS, Sievers and colleagues analyzed the genetic profile of 48 small colorectal polyps (6-9 mm) from 36 patients including conventional, serrated and hyperplastic adenomas. As expected, APC gene mutations represented the most frequent genetic event (67\% of all polyps). In addition pathogenic mutations in KRAS, FBXW7 and TP53 genes were also detected in $15 \%, 10 \%$, and $8 \%$ of all the analyzed polyps, respectively [57] (Table 2). BRAF p.V600E mutations were also detected in small colorectal polyps, above all in SSAs and HPs. Interestingly, a small percentage of these polyps were characterized by the simultaneous presence of pathological mutations in different driver genes including APC, KRAS, TP53 and FBXW7 [57]. These results support the "Big Bang" model of colorectal tumor development according to which different sub-clones are generated during the tumor growth leading to ITH [76].

By performing single-cell WES and bulk WES on both adenomas and carcinomas from two patients, $\mathrm{Wu}$ and colleagues described new early driver alterations in CRC. A mutation in the OR1B1 gene was described as an early causative event for adenoma development. Mutations in CSMD1, FBXO15, and TFAP2D genes were also identified as sub-clonal mutations contributing to the ITH [63] (Table 2).

Through WES and target sequencing, another study evaluated somatically mutated genes in both CNADs $(\mathrm{n}=135)$ and SSAs $(\mathrm{n}=14)$. In CNADs, APC gene mutations represented the most frequent causative event. KRTAP4-5 (rs411367), CTNNB1 (rs121913409), GOLGA8B (rs200544945), and TMPRSS13 (rs61900347), KRAS (rs1291913529, rs121913530) were also proposed as driver oncogenic mutations in CNADs [60]. In addition, mutations in the tumor suppressor genes FBXW7 and SOX9 were found to be driver events in CNADs [60] (Table 2).

In line with these results, a study on 11 colorectal adenoma-carcinoma pairs, found that alterations in TCF7L2 and TMPRSS13 genes also contributed to CRC initiation. Interestingly, the authors found two TCF7L2-adenoma-specific mutations [59] (Table 2). They also found recurrent mutations in the NRAS gene, despite being reported with a low frequency in another study $[59,64]$.

The pivotal role of alterations in the Wnt-pathway related genes in colorectal tumorigenesis was also supported in a retrospective analysis of 58 CNADs with different grades of dysplasia, 17 of which were classified as adenocarcinomas [58]. APC gene mutations frequently occurred in this study $(76.5 \%$ of cases). KRAS mutations were found in most of the adenomas analyzed (62.4\% of cases), particularly in pre-malignant and high-grade dysplasia adenomas. Mutations in other genes, including BCL2, FBXW7, GNAS, HNF1A, MLL2/KMT2D, MLL3/KMT2C, SYNE1, TCF7L2, NOTCH1, PBRM1, RET, RARA, and FN1, were also detected [58] (Table 2). Mutations in the Wnt-related genes CTNNB1, EP300, TCF7L2, and the AMER1 genes were also observed, but at a lower frequency, in accordance with previous data on adenomas with high grade dysplasia [65]. The authors also reported previously undescribed mutations in MTOR, ACVR1B, GNAQ, ATM, CNOT1, EP300, ARID2, RET, and MAP2K4 genes have been reported in colonic adenomas in this study [65] (Table 2).

Another study has helped to establishing which alterations, early identifiable in adenomatous tissues, may play a critical role in CRC development. The authors evaluated the genetic and molecular characteristics of multiple adenomatous tissues from 38 patients through WES and RNA sequencing. They analyzed the differences between cancer-adjacent polyps (CAPs) and cancer-free polyps (CFPs) and found a higher mutation rate in the first group. Interestingly, while both CAPs and CFPs shared causative mutations in the APC gene, somatic mutations in TP53, FBXW7, PIK3CA, KIAA1804, and SMAD2 were detected only in CAPs and were related to cancer progression [66] (Table 2).

\subsection{Colorectal Serrated Lesions}

Through an exome-sequencing based approach on peripheral blood or mouthwash samples, the first study to investigate the hereditary genetic alterations associated with the development of SSLs was conducted by Gala and colleagues on 20 unrelated patients 
with multiple SSLs, most of which met the clinical criteria for SPS. The authors found that loss of function germline mutations in genes involved in the regulation of senescence, particularly ATM, PIF1, TELO2, XAF1, and RBL1, led to the genetic predisposition of developing multiple SSLs. In addition, this study was the first to identified RNF43 R113X germline mutation as a causative driver gene for SPS onset. Genotyping one representative SSL from 19 individuals of the 20 enrolled patients, the authors found out that all the lesions, except one, carried the somatic BRAFV600E mutation [67] (Table 2).

The RNF43 gene encodes for an E3 ubiquitin-protein ligase implicated in the ubiquitination and internalization of the Frizzled receptors, thus representing a crucial negative regulator of the Wnt/ $\beta$-catenin signaling pathway [77-79].

After the first evidence suggesting the causative role of germline inactivating mutations in the RNF43 gene on SPS onset, another study confirmed the pathogenic role of hereditary RNF43 mutations in one SPS family and further demonstrated that somatic mutations in the RNF43 gene represent also a frequent event in SSLs (34\%), despite not being found in HPs. Importantly, in most sporadic SSLs/TSAs analyzed in this study, the authors found co-occurrent mutations in both RNF43 and BRAF genes (the latter were found only in SSLs/TSAs but not in CNADs) [68] (Table 2). Similar results were reported by Tsai and colleagues. In agreement with other studies, they observed that RNF43 mutations in TSAs are frequently associated with BRAF mutations (14/17 TSAs), rather than KRAS mutations (2/17 TSAs) [69] (Table 2).

Although RNF43 loss of function mutations have been found in both SSLs and TSAs, different studies have shown a higher frequency of somatic RNF43 mutations in TSAs rather than SSLs $[69,70]$ (Table 2). The presence of mutations in Wnt-related genes was investigated in another study in a series of SSLs with or without dysplasia. The authors found that RNF43 inactivating mutations constitute the most frequent event in dysplastic lesions, while APC and ZNRF3 alterations were only observed in a few cases (Table 2). Alterations in Wnt signaling components and the consequent $\beta$-catenin nuclear accumulation were characteristic of dysplastic lesions, while $B R A F$ mutations, found almost in all characterized lesions, did not depend on whether there was dysplasia or not [71].

Performing WES on both CNADs and SSLs, Lin and colleagues found no differences in the mutation frequencies between these adenoma subtypes. However, the mutational profile of CNADs and SSLs was different. The most frequent somatic mutations found in SSLs were BRAF (V600E; rs113488022) and KRTAP4-5 (rs411367). Somatic mutations in the KRTAP4-5 were found in both CNADs and SSLs, while APC gene mutations, observed in most CNADs, were not found in the SSLs analyzed [60] (Table 2). In fact, APC gene mutations were found in another study to be more common in CNADs and completely absent in HPs and SSLs, although APC mutations were observed in a small fraction of TSAs [70] (Table 2).

The BRAF V600E missense somatic mutation was observed in the $67 \%$ of cases in a study that prospectively analyzed 200 TSAs. In this study, BRAF-mutated adenomas, while having a MSS profile, frequently showed a CIMP-high profile [72] (Table 2). Recently, another study characterized the genetic and molecular profile of a small SSL series with dysplasia or carcinoma showing $\beta$-catenin nuclear accumulation in all the analyzed lesions, nearly all of which had BRAF mutations. By performing target sequencing, the authors found that about half of the lesions also had mutations in FBXW7, particularly MSI-H SSLs, while MSS SSLs partially harbored mutations in the TP53 gene. Somatic mutations in KIT, PTEN, SMAD4, and SMARC1B genes were also detected at low frequencies in the same case series [73] (Table 2).

$A P C$ gene inactivating mutations represent the most common initiating event during the development of CNADs [2,80]. In an evaluation of the frequency of APC gene alterations in the serrated pathway, compared with CNADs, truncating $A P C$ gene mutations occur over all at a low frequency in serrated lesions, particularly in SSLs, despite their higher rate in TSAs (Table 2). APC gene missense mutations have been reported more frequently in MSI$B R A F$-mutant serrated CRCs (Supplementary Table S2). Despite the low frequency of APC 
gene mutations, increased levels of nuclear $\beta$-catenin have been found in both dysplastic SSLs and TSAs, indicating that the hyperactivation of the Wnt $\beta$-catenin pathway might contribute to the malignant progression of serrated lesions with a mechanism that is probably not tied to the APC gene inactivation [74].

The R-Spondin (RSPO) gene fusions, leading to RSPO protein induction, represent an alternative mechanism leading to $\mathrm{Wnt} / \beta$-catenin signaling induction in TSAs. RSPO genes encode for leucine-rich repeat-containing G-protein coupled receptor (LGR) ligands and constitutes potent Wnt agonists, which impair the internalization of Frizzled receptors mediated by RNF43 and ZNRF3 [78,81]. RSPO fusions have been proposed as drivers in human CRC [82], and have been detected as causative genetic alterations in TSAs [68,70]. Sekine and colleagues found that PTPRK-RSPO3 fusions were the most frequent cause of RSPO overexpression in this setting [70,83]. In addition to the known and most representative RSPO fusion transcripts, PTPRK(exon 1)-RSPO3 and PTPRK(exon 7)-RSPO3, the authors revealed novel RSPO fusion isoforms involving the fusion of PTPRK exon 6 and 13 to RSPO3 exon 2, respectively, and the fusion of NRP1(exon 2/3) to RSPO2 exon2 [83]. The same authors confirmed previous results in a further TSAs series and identified EIF3E-RSPO2 and PIEZO1-RSPO2 fusions in a small percentage of traditional serrated lesions, which concurrently showed KRAS mutations [84]. Moreover, the analysis of precursor polyps associated with TSAs showed that the acquisition of genetic alterations in Wnt-related genes (such as RNF43, APC and CTNNB1) could occur during the transition from precursor polyps to TSAs, which was more frequent in TSAs [75] (Table 2).

This evidence supports the idea that, although the aberrant activation of the MAPK cascade has a pivotal role in the initiation of the serrated CRC pathway [73], Wnt/ $\beta$-catenin signaling hyperactivation is critical not only in the malignant progression of CNADs following the classical adenoma-carcinoma sequence, but also in the serrated pathway.

\section{Conclusions}

The main genetic, epigenetic, and molecular alterations driving the onset and progression of CRC in both hereditary and sporadic settings have frequently been investigated. The diffusion of NGS and transcriptomic technologies has led to the identification of new candidate driver genes and to improving the knowledge on the molecular mechanisms underlying the progression of colonic adenomas towards CRC development.

Figure 1 summarizes the most common mutated genes in both hereditary and sporadic settings emerging from the studies discussed in this review. Although the mutations of a few genes were shared among these different settings, the studies highlight the wide genetic heterogeneity of both early and advanced pre-cancerous lesions, thus making it difficult to develop effective therapeutic strategies.

Several studies have investigated the long-term CRC risk based on the endoscopic and histological characteristics of colonic lesions. However, studies on large series, simultaneously assessing the risk of developing CRC in relation to the histopathologic, genetic, and molecular characteristics of pre-cancerous lesions, are lacking.

In conclusion, the evaluation of the CRC risk based on the molecular characterization of early pre-cancerous colorectal lesions, both in hereditary and sporadic settings, may speed up the development of targeted preventive strategies. This would consequently define specific risk profiles, as well as identify those patients who would most benefit from strict endoscopic surveillance. Further studies will be pivotal to establish the individual $\mathrm{CRC}$ risk according to the genetic alterations detectable in early colorectal lesions and to define the impact of such characterization in clinical practice. 


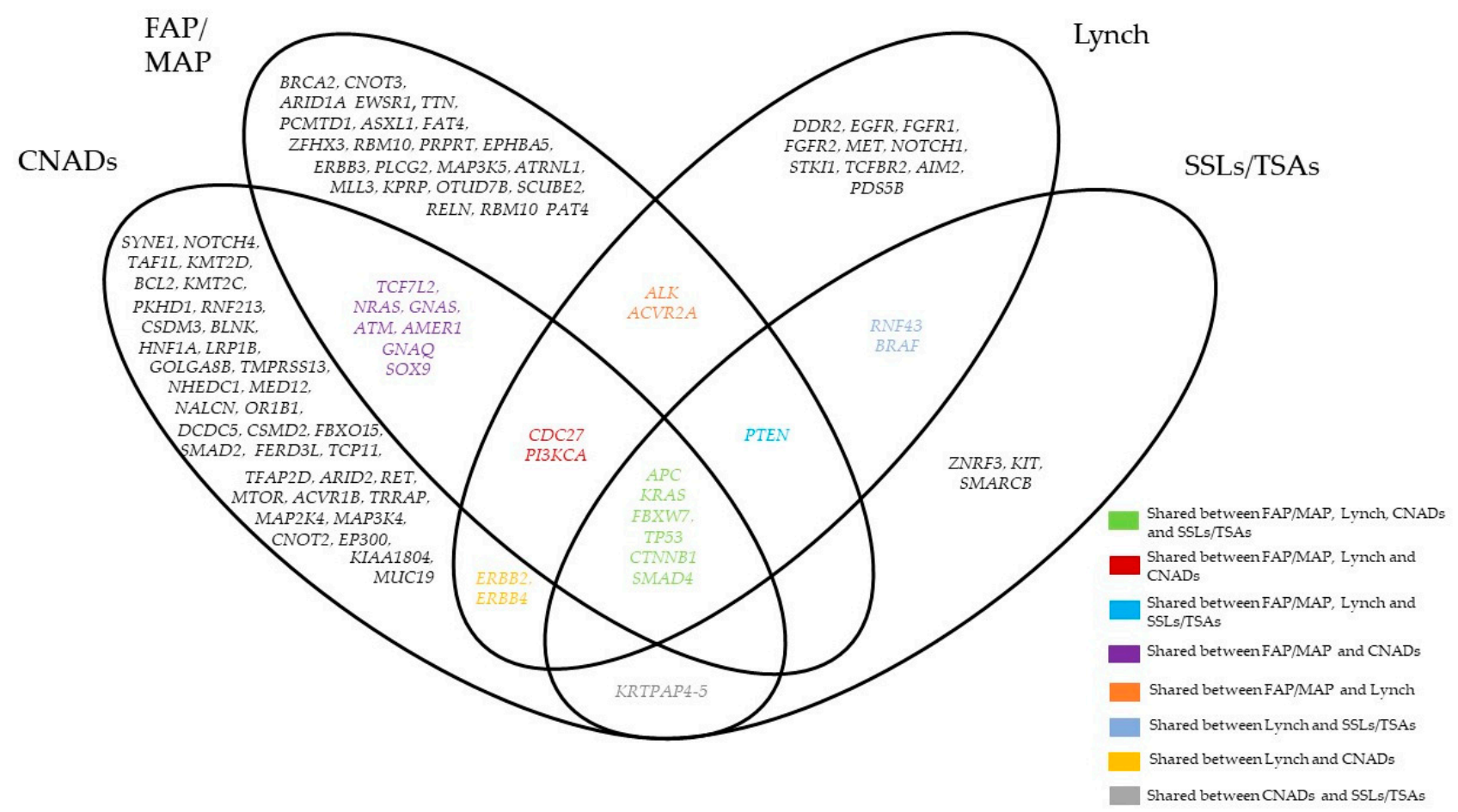

Figure 1. Graphical representation of the most frequent mutated genes in FAP (Familial Adenomatous Polyposis)/MAP (MUTYH-associated Polyposis), Lynch, CNADs (Conventional Colorectal Adenomas) and SSLs (Sessile Serrated Lesions) /TSAs (Traditional Serrated Lesions emerging from the studies discussed in this review. The graph does not refer to any statistics.

Supplementary Materials: The following are available online at https:/ /www.mdpi.com/article/10 .3390/cancers13092081/s1, Table S1: Studies evaluating cumulative CRC risk in Lynch syndrome in relation to germline mutations in MMR gene; Table S2: Studies evaluating somatic mutations in sporadic CRC. References [49-52,58,59,63,68,69,74] are cited in the Supplementary Material.

Author Contributions: C.A. and A.P. searched for and analyzed the literature for the article and wrote the manuscript; G.P., F.B. (Francesco Buttitta), and F.B. (Franco Bazzoli) critically reviewed the manuscript; L.L. and L.R. edited and reviewed the manuscript and critically contributed to the discussion of the content. All authors have read and agreed to the published version of the manuscript.

Funding: This research was funded by the AIRC Foundation for Cancer Research (Grant number: IG 21723 to L.R.).

Conflicts of Interest: The authors declare no conflict of interest.

\section{References}

1. Dekker, E.; Tanis, P.J.; Vleugels, J.L.A.; Kasi, P.M.; Wallace, M.B. Colorectal cancer. Lancet 2019, 394, 1467-1480. [CrossRef]

2. Vogelstein, B.; Fearon, E.R.; Hamilton, S.R.; Kern, S.E.; Preisinger, A.C.; Leppert, M.; Smits, A.M.M.; Bos, J.L.; Smits, A.M.; Bos, J.L. Genetic alterations during colorectal-Tumor development. N. Engl. J. Med. 1988, 319, 525-532. [CrossRef]

3. Church, J.M. Clinical significance of small colorectal polyps. Dis. Colon Rectum 2004, 47, 481-485. [CrossRef]

4. Leggett, B.; Whitehall, V. Role of the serrated pathway in colorectal cancer pathogenesis. Gastroenterology 2010, 138, 2088-2100. [CrossRef] [PubMed]

5. Huang, C.S.; Farraye, F.A.; Yang, S.; O’Brien, M.J. The clinical significance of serrated polyps. Am. J. Gastroenterol. 2011, 106, 229-240. [CrossRef] [PubMed]

6. Lu, F.-I.; van Niekerk, D.W.; Owen, D.; Tha, S.P.L.; Turbin, D.A.; Webber, D.L. Longitudinal outcome study of sessile serrated adenomas of the colorectum: An increased risk for subsequent right-sided colorectal carcinoma. Am. J. Surg. Pathol. 2010, 34, 927-934. [CrossRef] [PubMed]

7. Snover, D.C. Update on the serrated pathway to colorectal carcinoma. Hum. Pathol. 2011, 42, 1-10. [CrossRef] 
8. Pai, R.K.; Mäkinen, M.J.; Rosty, C. Colorectal serrated lesions and polyps. In WHO Classification of Tumours of the Digestive System; Nagtegaal, I.D., Arends, M.J., Odze, R.D., Lam, A.K., Eds.; Lyon IARC Press: Lyon, France, 2019; pp. 163-169.

9. Snover, D.C.; Ahnen, D.J.; Burt, R.W. Serrated polyps of the colon and rectum and serrated polyposis. In WHO Classification of Tumours of the Digestive System; Nagtegaal, I.D., Arends, M.J., Odze, R.D., Lam, A.K., Eds.; Lyon IARC Press: Lyon, France, 2019.

10. Løberg, M.; Kalager, M.; Holme, Ø.; Hoff, G.; Adami, H.-O.; Bretthauer, M. Long-term colorectal-cancer mortality after adenoma removal. N. Engl. J. Med. 2014, 371, 799-807. [CrossRef] [PubMed]

11. Click, B.; Pinsky, P.; Hickey, T.; Doroudi, M.; Schoen, R. Association of colonoscopy adenoma findings with long-term colorectal cancer incidence. JAMA 2018, 319, 2021-2031. [CrossRef] [PubMed]

12. He, X.; Hang, D.; Wu, K.; Nayor, J.; Drew, D.; Giovannucci, E.; Ogino, S.; Chan, A.; Song, M. Long-term risk of colorectal cancer after removal of conventional adenomas and serrated polyps. Gastroenterology 2020, 158, 852-861. [CrossRef]

13. Lee, J.; Jensen, C.; Levin, T.; Doubeni, C.; Zauber, A.; Chubak, J.; Kamineni, A.; Schottinger, J.; Ghai, N.; Udaltsova, N.; et al. Longterm risk of colorectal cancer and related death after adenoma removal in a large, community-based population. Gastroenterology 2020, 158, 884-894. [CrossRef] [PubMed]

14. Holme, Ø.; Bretthauer, M.; Eide, T.J.; Løberg, E.M.; Grzyb, K.; Løberg, M.; Kalager, M.; Adami, H.O.; Kjellevold, Ø.; Hoff, G. Long-term risk of colorectal cancer in individuals with serrated polyps. Gut 2015, 64, 929-936. [CrossRef]

15. Erichsen, R.; Baron, J.A.; Hamilton-Dutoit, S.J.; Snover, D.C.; Torlakovic, E.E.; Pedersen, L.; Frøslev, T.; Vyberg, M.; Hamilton, S.R.; Sørensen, H.T. Increased risk of colorectal cancer development among patients with serrated polyps. Gastroenterology 2016, 150, 895-902. [CrossRef]

16. Song, M.; Emilsson, L.; Bozorg, S.R.; Nguyen, L.H.; Joshi, A.D.; Staller, K.; Nayor, J.; Chan, A.T.; Ludvigsson, J.F. Risk of colorectal cancer incidence and mortality after polypectomy: A Swedish record-linkage study. Lancet Gastroenterol. Hepatol. 2020, 5, 537-547. [CrossRef]

17. Vasen, H.F.A.; Tomlinson, I.; Castells, A. Clinical management of hereditary colorectal cancer syndromes. Nat. Rev. Gastroenterol. Hepatol. 2015, 12, 88-97. [CrossRef] [PubMed]

18. Edelstein, D.L.; Axilbund, J.E.; Hylind, L.M.; Romans, K.; Griffin, C.A.; Cruz-Correa, M.; Giardiello, F.M. Serrated polyposis: Rapid and relentless development of colorectal neoplasia. Gut 2013, 62, 404-408. [CrossRef]

19. Colussi, D.; Brandi, G.; Bazzoli, F.; Ricciardiello, L. Molecular pathways involved in colorectal cancer: Implications for disease behavior and prevention. Int. J. Mol. Sci. 2013, 14, 16365-16385. [CrossRef]

20. Cancer Genome Atlas Network, T.C.G.A. Comprehensive molecular characterization of human colon and rectal cancer. Nature 2012, 487, 330-337. [CrossRef]

21. Shiovitz, S.; Copeland, W.K.; Passarelli, M.N.; Burnett-Hartman, A.N.; Grady, W.M.; Potter, J.D.; Gallinger, S.; Buchanan, D.D.; Rosty, C.; Win, A.K.; et al. Characterisation of familial colorectal cancer Type X, Lynch syndrome, and non-familial colorectal cancer. Br. J. Cancer 2014, 111. [CrossRef]

22. Yurgelun, M.B.; Kulke, M.H.; Fuchs, C.S.; Allen, B.A.; Uno, H.; Hornick, J.L.; Ukeagbu, C.I.; Brais, L.K.; McNamara, P.G.; Mayer, R.J.; et al. Cancer susceptibility gene mutations in individuals with colorectal cancer. J. Clin. Oncol. 2017, 35. [CrossRef] [PubMed]

23. Yu, J.; Wu, W.K.K.; Li, X.; He, J.; Li, X.X.; Ng, S.S.M.; Yu, C.; Gao, Z.; Yang, J.; Li, M.; et al. Novel recurrently mutated genes and a prognostic mutation signature in colorectal cancer. Gut 2015, 64, 636-645. [CrossRef]

24. Alexandrov, L.B.; Kim, J.; Haradhvala, N.J.; Huang, M.N.; Tian Ng, A.W.; Wu, Y.; Boot, A.; Covington, K.R.; Gordenin, D.A.; Bergstrom, E.N.; et al. The repertoire of mutational signatures in human cancer. Nature 2020, 578, 94-101. [CrossRef]

25. Guinney, J.; Dienstmann, R.; Wang, X.; de Reyniès, A.; Schlicker, A.; Soneson, C.; Marisa, L.; Roepman, P.; Nyamundanda, G.; Angelino, P.; et al. The consensus molecular subtypes of colorectal cancer. Nat. Med. 2015, 21, 1350-1356. [CrossRef] [PubMed]

26. Grolleman, J.E.; Díaz-Gay, M.; Franch-Expósito, S.; Castellví-Bel, S.; de Voer, R.M. Somatic mutational signatures in polyposis and colorectal cancer. Mol. Asp. Med. 2019, 69, 62-72. [CrossRef] [PubMed]

27. Doxey, B.W.; Kuwada, S.K.; Burt, R.W. Inherited polyposis syndromes: Molecular mechanisms, clinicopathology, and genetic testing. Clin. Gastroenterol. Hepatol. 2005, 3. [CrossRef]

28. Aretz, S.; Stienen, D.; Friedrichs, N.; Stemmler, S.; Uhlhaas, S.; Rahner, N.; Propping, P.; Friedl, W. Somatic APC mosaicism: A frequent cause of familial adenomatous polyposis (FAP). Hum. Mutat. 2007, 28, 985-992. [CrossRef] [PubMed]

29. Ciavarella, M.; Miccoli, S.; Prossomariti, A.; Pippucci, T.; Bonora, E.; Buscherini, F.; Palombo, F.; Zuntini, R.; Balbi, T.; Ceccarelli, C.; et al. Somatic APC mosaicism and oligogenic inheritance in genetically unsolved colorectal adenomatous polyposis patients. Eur. J. Hum. Genet. 2018, 26, 387-395. [CrossRef] [PubMed]

30. Nielsen, M.; Joerink-van de Beld, M.C.; Jones, N.; Vogt, S.; Tops, C.M.; Vasen, H.F.A.; Sampson, J.R.; Aretz, S.; Hes, F.J. Analysis of MUTYH genotypes and colorectal phenotypes in patients With MUTYH-associated polyposis. Gastroenterology 2009, 136, 471-476. [CrossRef] [PubMed]

31. Ma, H.; Brosens, L.A.A.; Offerhaus, G.J.A.; Giardiello, F.M.; de Leng, W.W.J.; Montgomery, E.A. Pathology and genetics of hereditary colorectal cancer. Pathology 2018, 50, 49-59. [CrossRef]

32. Borras, E.; San Lucas, F.A.; Chang, K.; Zhou, R.; Masand, G.; Fowler, J.; Mork, M.E.; You, Y.N.; Taggart, M.W.; McAllister, F.; et al. Genomic Landscape of Colorectal Mucosa and Adenomas. Cancer Prev. Res. 2016, 9, 417-427. [CrossRef]

33. Gausachs, M.; Borras, E.; Chang, K.; Gonzalez, S.; Azuara, D.; Delgado Amador, A.; Lopez-Doriga, A.; San Lucas, F.A.; Sanjuan, X.; Paules, M.J.; et al. Mutational Heterogeneity in APC and KRAS Arises at the Crypt Level and Leads to Polyclonality in Early Colorectal Tumorigenesis. Clin. Cancer Res. 2017, 23, 5936-5947. [CrossRef] 
34. Li, J.; Wang, R.; Zhou, X.; Wang, W.; Gao, S.; Mao, Y.; Wu, X.; Guo, L.; Liu, H.; Wen, L.; et al. Genomic and transcriptomic profiling of carcinogenesis in patients with familial adenomatous polyposis. Gut 2020, 69, 1283-1293. [CrossRef]

35. Rashid, M.; Fischer, A.; Wilson, C.H.; Tiffen, J.; Rust, A.G.; Stevens, P.; Idziaszczyk, S.; Maynard, J.; Williams, G.T.; Mustonen, V.; et al. Adenoma development in familial adenomatous polyposis and MUTYH -associated polyposis: Somatic landscape and driver genes. J. Pathol. 2016, 238, 98-108. [CrossRef]

36. Sekine, S.; Mori, T.; Ogawa, R.; Tanaka, M.; Yoshida, H.; Taniguchi, H.; Nakajima, T.; Sugano, K.; Yoshida, T.; Kato, M.; et al. Mismatch repair deficiency commonly precedes adenoma formation in Lynch syndrome-Associated colorectal tumorigenesis. Mod. Pathol. 2017, 30, 1144-1151. [CrossRef]

37. Mäki-Nevala, S.; Valo, S.; Ristimäki, A.; Sarhadi, V.; Knuutila, S.; Nyström, M.; Renkonen-Sinisalo, L.; Lepistö, A.; Mecklin, J.-P.; Peltomäki, P. DNA methylation changes and somatic mutations as tumorigenic events in Lynch syndrome-associated adenomas retaining mismatch repair protein expression. EBioMedicine 2019, 39, 280-291. [CrossRef]

38. Binder, H.; Hopp, L.; Schweiger, M.R.; Hoffmann, S.; Jühling, F.; Kerick, M.; Timmermann, B.; Siebert, S.; Grimm, C.; Nersisyan, L.; et al. Genomic and transcriptomic heterogeneity of colorectal tumours arising in Lynch syndrome. J. Pathol. 2017, 243, 242-254. [CrossRef]

39. Major, M.B.; Camp, N.D.; Berndt, J.D.; Yi, X.; Goldenberg, S.J.; Hubbert, C.; Biechele, T.L.; Gingras, A.-C.; Zheng, N.; MacCoss, M.J.; et al. Wilms tumor suppressor WTX negatively regulates WNT/ -catenin signaling. Science 2007, 316, 1043-1046. [CrossRef] [PubMed]

40. Sanz-Pamplona, R.; Lopez-Doriga, A.; Pare-Brunet, L.; Lazaro, K.; Bellido, F.; Alonso, M.H.; Ausso, S.; Guino, E.; Beltran, S.; Castro-Giner, F.; et al. Exome sequencing reveals AMER1 as a frequently mutated gene in colorectal cancer. Clin. Cancer Res. 2015, 21, 4709-4718. [CrossRef] [PubMed]

41. Thomas, L.E.; Hurley, J.J.; Meuser, E.; Jose, S.; Ashelford, K.E.; Mort, M.; Idziaszczyk, S.; Maynard, J.; Brito, H.L.; Harry, M.; et al. Burden and profile of somatic mutation in duodenal adenomas from patients with familial adenomatous- and MUTYH -associated polyposis. Clin. Cancer Res. 2017, 23, 6721-6732. [CrossRef] [PubMed]

42. Lynch, H.T.; Snyder, C.L.; Shaw, T.G.; Heinen, C.D.; Hitchins, M.P. Milestones of Lynch syndrome: 1895-2015. Nat. Rev. Cancer 2015, 15, 181-194. [CrossRef]

43. De Jong, A.E.; Morreau, H.; Van Puijenbroek, M.; Eilers, P.H.C.; Wijnen, J.; Nagengast, F.M.; Griffioen, G.; Cats, A.; Menko, F.H.; Kleibeuker, J.H.; et al. The role of mismatch repair gene defects in the development of adenomas in patients with HNPCC. Gastroenterology 2004, 126, 42-48. [CrossRef] [PubMed]

44. Tanaka, M.; Nakajima, T.; Sugano, K.; Yoshida, T.; Taniguchi, H.; Kanemitsu, Y.; Nagino, M.; Sekine, S. Mismatch repair deficiency in Lynch syndrome-associated colorectal adenomas is more prevalent in older patients. Histopathology 2016, 69, 322-328. [CrossRef] [PubMed]

45. Valo, S.; Kaur, S.; Ristimäki, A.; Renkonen-Sinisalo, L.; Järvinen, H.; Mecklin, J.P.; Nyström, M.; Peltomäki, P. DNA hypermethylation appears early and shows increased frequency with dysplasia in Lynch syndrome-associated colorectal adenomas and carcinomas. Clin. Epigenetics 2015, 7, 71. [CrossRef] [PubMed]

46. Ahadova, A.; Seppälä, T.T.; Engel, C.; Gallon, R.; Burn, J.; Holinski-Feder, E.; Steinke-Lange, V.; Möslein, G.; Nielsen, M.; ten Broeke, S.W.; et al. The "unnatural" history of colorectal cancer in Lynch syndrome: Lessons from colonoscopy surveillance. Int. J. Cancer 2021, 148, 800-811. [CrossRef]

47. Boland, C.R.; Goel, A. Microsatellite instability in colorectal cancer. Gastroenterology 2010, 138, 2073-2087. [CrossRef]

48. Yurgelun, M.B.; Goel, A.; Hornick, J.L.; Sen, A.; Turgeon, D.K.; Ruffin IV, M.T.; Marcon, N.E.; Baron, J.A.; Bresalier, R.S.; Syngal, S.; et al. Microsatellite instability and DNA mismatch repair protein deficiency in lynch syndrome colorectal polyps. Cancer Prev. Res. 2012, 5, 574-582. [CrossRef] [PubMed]

49. Engel, C.; Ahadova, A.; Seppälä, T.T.; Aretz, S.; Bigirwamungu-Bargeman, M.; Bläker, H.; Bucksch, K.; Büttner, R.; de Vos Tot Nederveen Cappel, W.T.; Endris, V.; et al. Associations of pathogenic variants in MLH1, MSH2, and MSH6 with risk of colorectal adenomas and tumors and with somatic mutations in patients with Lynch syndrome. Gastroenterology 2020, 158, 1326-1333. [CrossRef]

50. Lamba, M.; Wakeman, C.; Ebel, R.; Hamilton, S.; Frampton, C.; Kiesanowski, M.; Griffiths, B.; Keating, J.; Parry, S.; ChalmersWatson, T. Associations between mutations in MSH6 and PMS2 and risk of surveillance-detected colorectal cancer. Clin. Gastroenterol. Hepatol. 2020, 18, 2768-2774. [CrossRef]

51. Møller, P.; Seppälä, T.T.; Bernstein, I.; Holinski-Feder, E.; Sala, P.; Evans, D.G.; Lindblom, A.; Macrae, F.; Blanco, I.; Sijmons, R.H.; et al. Cancer risk and survival in path-MMR carriers by gene and gender up to 75 years of age: A report from the prospective Lynch syndrome database. Gut 2018, 67, 1306-1316. [CrossRef]

52. ten Broeke, S.W.; van Bavel, T.C.; Jansen, A.M.L.; Gómez-García, E.; Hes, F.J.; van Hest, L.P.; Letteboer, T.G.W.; Olderode-Berends, M.J.W.; Ruano, D.; Spruijt, L.; et al. Molecular background of colorectal tumors from patients with Lynch syndrome associated with germline variants in PMS2. Gastroenterology 2018, 155, 844-851. [CrossRef]

53. Ahadova, A.; von Knebel Doeberitz, M.; Bläker, H.; Kloor, M. CTNNB1-mutant colorectal carcinomas with immediate invasive growth: A model of interval cancers in Lynch syndrome. Fam. Cancer 2016, 15, 579-586. [CrossRef]

54. Ahadova, A.; Gallon, R.; Gebert, J.; Ballhausen, A.; Endris, V.; Kirchner, M.; Stenzinger, A.; Burn, J.; von Knebel Doeberitz, M.; Bläker, H.; et al. Three molecular pathways model colorectal carcinogenesis in Lynch syndrome. Int. J. Cancer 2018, 143, 139-150. [CrossRef] 
55. Markowitz, S.D.; Bertagnolli, M.M. Molecular basis of colorectal cancer. N. Engl. J. Med. 2009, 361, 2449-2460. [CrossRef]

56. Lee-Six, H.; Olafsson, S.; Ellis, P.; Osborne, R.J.; Sanders, M.A.; Moore, L.; Georgakopoulos, N.; Torrente, F.; Noorani, A.; Goddard, M.; et al. The landscape of somatic mutation in normal colorectal epithelial cells. Nature 2019, 574, 532-537. [CrossRef]

57. Sievers, C.K.; Zou, L.S.; Pickhardt, P.J.; Matkowskyj, K.A.; Albrecht, D.M.; Clipson, L.; Bacher, J.W.; Pooler, B.D.; Moawad, F.J.; Cash, B.D.; et al. Subclonal diversity arises early even in small colorectal tumours and contributes to differential growth fates. Gut 2017, 66, 2132-2140. [CrossRef]

58. Karczmarski, J.; Goryca, K.; Pachlewski, J.; Dabrowska, M.; Pysniak, K.; Paziewska, A.; Kulecka, M.; Lenarcik, M.; Mroz, A.; Mikula, M.; et al. Mutation profiling of premalignant colorectal neoplasia. Gastroenterol. Res. Pract. 2019, 2019, 2542640. [CrossRef] [PubMed]

59. Lee, S.H.; Yoo, J.; Song, Y.S.; Lim, C.H.; Kim, T.M. Mutation analysis of colorectal and gastric carcinomas originating from adenomas: Insights into genomic evolution associated with malignant progression. Cancers 2020, 12, 325. [CrossRef] [PubMed]

60. Lin, S.-H.; Raju, G.S.; Huff, C.; Ye, Y.; Gu, J.; Chen, J.-S.; Hildebrandt, M.A.T.; Liang, H.; Menter, D.G.; Morris, J.; et al. The somatic mutation landscape of premalignant colorectal adenoma. Gut 2018, 67, 1299-1305. [CrossRef] [PubMed]

61. Saito, T.; Niida, A.; Uchi, R.; Hirata, H.; Komatsu, H.; Sakimura, S.; Hayashi, S.; Nambara, S.; Kuroda, Y.; Ito, S.; et al. A temporal shift of the evolutionary principle shaping intratumor heterogeneity in colorectal cancer. Nat. Commun. 2018, 9, 2884. [CrossRef]

62. Testa, U.; Pelosi, E.; Castelli, G. Colorectal cancer: Genetic abnormalities, tumor progression, tumor heterogeneity, clonal evolution and tumor-initiating cells. Med. Sci. 2018, 6, 31. [CrossRef]

63. Wu, H.; Zhang, X.Y.; Hu, Z.; Hou, Q.; Zhang, H.; Li, Y.; Li, S.; Yue, J.; Jiang, Z.; Weissman, S.M.; et al. Evolution and heterogeneity of non-hereditary colorectal cancer revealed by single-cell exome sequencing. Oncogene 2017, 36, 2857-2867. [CrossRef]

64. Irahara, N.; Baba, Y.; Nosho, K.; Shima, K.; Yan, L.; Dias-Santagata, D.; Iafrate, A.J.; Fuchs, C.S.; Haigis, K.M.; Ogino, S. NRAS mutations are rare in colorectal cancer. Diagn. Mol. Pathol. 2010, 19, 157-163. [CrossRef]

65. Lee, S.H.; Jung, S.H.; Kim, T.M.; Rhee, J.K.; Park, H.C.; Kim, M.S.; Kim, S.S.; An, C.H.; Lee, S.H.; Chung, Y.J. Whole-exome sequencing identified mutational profiles of high-grade colon adenomas. Oncotarget 2017, 8, 6579-6588. [CrossRef]

66. Druliner, B.R.; Wang, P.; Bae, T.; Baheti, S.; Slettedahl, S.; Mahoney, D.; Vasmatzis, N.; Xu, H.; Kim, M.; Bockol, M.; et al. Molecular characterization of colorectal adenomas with and without malignancy reveals distinguishing genome, transcriptome and methylome alterations. Sci. Rep. 2018, 8, 3161. [CrossRef] [PubMed]

67. Gala, M.K.; Mizukami, Y.; Le, L.P.; Moriichi, K.; Austin, T.; Yamamoto, M.; Lauwers, G.Y.; Bardeesy, N.; Chung, D.C. Germline mutations in oncogene-induced senescence pathways are associated with multiple sessile serrated adenomas. Gastroenterology 2014, 146, 520-529.e6. [CrossRef] [PubMed]

68. Yan, H.H.N.; Lai, J.C.W.; Ho, S.L.; Leung, W.K.; Law, W.L.; Lee, J.F.Y.; Chan, A.K.W.; Tsui, W.Y.; Chan, A.S.Y.; Lee, B.C.H.; et al. RNF43 germline and somatic mutation in serrated neoplasia pathway and its association with BRAF mutation. Gut 2017, 66, 1645-1656. [CrossRef]

69. Tsai, J.-H.; Liau, J.-Y.; Yuan, C.-T.; Lin, Y.-L.; Tseng, L.-H.; Cheng, M.-L.; Jeng, Y.-M. RNF43 Is an Early and Specific Mutated Gene in the Serrated Pathway, With Increased Frequency in Traditional Serrated Adenoma and Its Associated Malignancy. Am. J. Surg. Pathol. 2016, 40, 1352-1359. [CrossRef] [PubMed]

70. Sekine, S.; Yamashita, S.; Tanabe, T.; Hashimoto, T.; Yoshida, H.; Taniguchi, H.; Kojima, M.; Shinmura, K.; Saito, Y.; Hiraoka, N.; et al. Frequent PTPRK-RSPO3 fusions and RNF43 mutations in colorectal traditional serrated adenoma. J. Pathol. 2016, 239, 133-138. [CrossRef]

71. Hashimoto, T.; Yamashita, S.; Yoshida, H.; Taniguchi, H.; Ushijima, T.; Yamada, T.; Saito, Y.; Ochiai, A.; Sekine, S.; Hiraoka, N. WNT pathway gene mutations are associated with the presence of dysplasia in colorectal sessile serrated adenoma/polyps. Am. J. Surg. Pathol. 2017, 41, 1188-1197. [CrossRef]

72. Bettington, M.L.; Walker, N.I.; Rosty, C.; Brown, I.S.; Clouston, A.D.; McKeone, D.M.; Pearson, S.-A.; Klein, K.; Leggett, B.A.; Whitehall, V.L. A clinicopathological and molecular analysis of 200 traditional serrated adenomas. Mod. Pathol. 2015, 28, 414-427. [CrossRef]

73. Murakami, T.; Akazawa, Y.; Yatagai, N.; Hiromoto, T.; Sasahara, N.; Saito, T.; Sakamoto, N.; Nagahara, A.; Yao, T. Molecular characterization of sessile serrated adenoma/polyps with dysplasia/carcinoma based on immunohistochemistry, next-generation sequencing, and microsatellite instability testing: A case series study. Diagn. Pathol. 2018, 13, 88. [CrossRef]

74. Borowsky, J.; Dumenil, T.; Bettington, M.; Pearson, S.A.; Bond, C.; Fennell, L.; Liu, C.; McKeone, D.; Rosty, C.; Brown, I.; et al. The role of APC in WNT pathway activation in serrated neoplasia. Mod. Pathol. 2018, 31, 495-504. [CrossRef]

75. Hashimoto, T.; Ogawa, R.; Yoshida, H.; Taniguchi, H.; Kojima, M.; Saito, Y.; Sekine, S. Acquisition of WNT pathway gene alterations coincides with the transition from precursor polyps to traditional serrated adenomas. Am. J. Surg. Pathol. 2019, 43, 132-139. [CrossRef]

76. Sottoriva, A.; Kang, H.; Ma, Z.; Graham, T.A.; Salomon, M.P.; Zhao, J.; Marjoram, P.; Siegmund, K.; Press, M.F.; Shibata, D.; et al. A Big Bang model of human colorectal tumor growth. Nat. Genet. 2015, 47, 209-216. [CrossRef]

77. Koo, B.-K.; Spit, M.; Jordens, I.; Low, T.Y.; Stange, D.E.; van de Wetering, M.; van Es, J.H.; Mohammed, S.; Heck, A.J.R.; Maurice, M.M.; et al. Tumour suppressor RNF43 is a stem-cell E3 ligase that induces endocytosis of Wnt receptors. Nature 2012, 488, 665-669. [CrossRef]

78. de Lau, W.; Peng, W.C.; Gros, P.; Clevers, H. The R-spondin/Lgr5/Rnf43 module: Regulator of Wnt signal strength. Genes Dev. 2014, 28, 305-316. [CrossRef] [PubMed] 
79. Takahashi, N.; Yamaguchi, K.; Ikenoue, T.; Fujii, T.; Furukawa, Y. Identification of Two Wnt-Responsive Elements in the Intron of RING Finger Protein 43 (RNF43) Gene. PLoS ONE 2014, 9, e86582. [CrossRef] [PubMed]

80. Jen, J.; Powell, S.M.; Papadopoulos, N.; Smith, K.J.; Hamilton, S.R.; Vogelstein, B.; Kinzler, K.W. Molecular determinants of dysplasia in colorectal lesions. Cancer Res. 1994, 54, 5523-5526. [PubMed]

81. Carmon, K.; Gong, X.; Lin, Q.; Thomas, A.; Liu, Q. R-spondins function as ligands of the orphan receptors LGR4 and LGR5 to regulate Wnt/beta-catenin signaling. Proc. Natl. Acad. Sci. USA 2011, 108, 11452-11457. [CrossRef]

82. Seshagiri, S.; Stawiski, E.W.; Durinck, S.; Modrusan, Z.; Storm, E.E.; Conboy, C.B.; Chaudhuri, S.; Guan, Y.; Janakiraman, V.; Jaiswal, B.S.; et al. Recurrent R-spondin fusions in colon cancer. Nature 2012, 488, 660-664. [CrossRef] [PubMed]

83. Sekine, S.; Ogawa, R.; Hashimoto, T.; Motohiro, K.; Yoshida, H.; Taniguchi, H.; Saito, Y.; Yasuhiro, O.; Ochiai, A.; Hiraoka, N. Comprehensive characterization of RSPO fusions in colorectal traditional serrated adenomas. Histopathology 2017, 71, 601-609. [CrossRef] [PubMed]

84. Hashimoto, T.; Ogawa, R.; Yoshida, H.; Taniguchi, H.; Kojima, M.; Saito, Y.; Sekine, S. EIF3E-RSPO2 and PIEZO1-RSPO2 fusions in colorectal traditional serrated adenoma. Histopathology 2019, 75, 266-273. [CrossRef] [PubMed] 